\title{
Etymological Aspects of Idiomatic and Proverbial Expressions in the Lexicographic Development of Sesotho sa Leboa - A Semantic Analysis*
}

V.M. Mojela, Sesotho sa Leboa National Lexicography Unit, University of the North, Polokwane, Republic of South Africa (mojelav@unorth.ac.za)

\begin{abstract}
Idiomatic and proverbial expressions are important components of the oral tradition of Sesotho sa Leboa, and therefore a knowledge of the literal meaning of words as they appear in dictionaries without inclusion of their figurative meaning seems to be a shortcoming. An idiom or a proverb possesses one basic meaning, i.e. the meaning to which the idiom or proverb is basically meant to refer, but each idiom or proverb is made up of several lexical items. Each of these lexical items has its own meaning, which usually differs from the figurative sense of the idiom or proverb. Even though the meaning of the words in an idiomatic or proverbial expression seems to differ from the sense of the idiom or proverb, there is to a certain extent a relationship. It is this relationship which lexicographers can assist to explain in their definitions in order to clarify both the literal and the figurative meanings of words in Sesotho sa Leboa.

This article aims to stress the importance of having specialized dictionaries which will give users detailed etymological explanations of the meaning of idiomatic and proverbial expressions as used in Sesotho sa Leboa. The etymological analysis of the meaning of these lexical items (idioms and proverbs) will provide a better understanding of these expressions and enrich dictionaries with detailed definitions. This will create a better understanding of the relationship between the literal meanings of the expressions and their real (i.e. figurative) meanings.
\end{abstract}

Keywords: DIACHRONIC ANALYSIS, ETYMOLOGY, FIGURATIVE EXPRESSION, IDIOM, LEMMATIZATION, LEXICOLOGY, METAPHOR, METAPHORIC EXPRESSION, PROVERB, SYNCHRONIC ANALYSIS, TERMINOGRAPHY.

Opsomming: Etimologiese aspekte van idiomatiese en spreekwoordelike uitdrukkings in die leksikografiese ontwikkeling van Sesotho sa Leboa - 'n semantiese ontleding. Idiomatiese en spreekwoordelike uitdrukkings is belangrike komponente van die mondelinge tradisie van Sesotho sa Leboa en gevolglik skyn die letterlike betekenis van woorde soos hulle in woordeboeke voorkom sonder insluiting van hul figuurlike betekenis, ' $n$ tekortkoming te wees. ' $n$ Idioom of spreekwoord besit een basiese betekenis, d.i. die betekenis

* This article is a revised version of a paper presented at the Seventh International Conference of the African Association for Lexicography, organised by the Dictionary Unit of South African English, Rhodes University, Grahamstown, Republic of South Africa, 8-10 July 2002.

Lexikos 14 (AFRILEX-reeks/series 14: 2004): 331-339 
waarna die idoom of spreekwoord bedoel is om basies te verwys, maar elke idioom of spreekwoord bestaan uit verskeie leksikale items. Hierdie leksikale items het elk sy eie betekenis wat gewoonlik verskil van die figuurlike betekenis van die idioom of spreekwoord. Selfs al skyn die betekenis van die woorde in 'n idiomatiese of spreekwoordelike uitdrukking te verskil van die idioom of spreekwoord, is daar in sekere mate 'n verwantskap. Dit is hierdie verwantskap wat leksikograwe kan help om in hul definisies te verklaar ten einde sowel die letterlike as die figuurlike betekenisse van woorde in Sesotho sa Leboa te belig.

Die doel van hierdie artikel is om die belangrikheid te beklemtoon van die besit van gespesialiseerde woordeboeke wat gebruikers uitvoerige etimologiese verklarings sal gee van idiomatiese en spreekwoordelike uitdrukkings soos in Sesotha sa Leboa gebruik. Die etimologiese ontleding van hierdie leksikale items (idiome en spreekwoorde) sal 'n beter begrip van hierdie uitdrukkings verskaf en woordeboeke met uitvoerige definisies verryk. Dit sal 'n beter begrip van die verhouding tussen die letterlike betekenisse van die uitdrukkings en hul werklike (d.i. figuurlike) betekenisse bewerkstellig.

Sleutelwoorde: DIACHRONIESE ONTLEDING, ETIMOLOGIE, FIGUURLIKE UITDRUKKING, IDIOOM, LEKSIKOLOGIE, LEMMATISERING, METAFOOR, METAFORIESE UITDRUKKING, SINCHRONIESE ONTLEDING, SPREEKWOORD, TERMINOGRAFIE

\section{Introduction}

Idioms and proverbs are figures of speech found in most, if not all languages around the world. They all have one thing in common, i.e. they use figures of speech to express figurative meanings in their culture, and in most cases these figures of speech include idioms and proverbs. These idioms and proverbs are important carriers of culture in the communities.

The main objective of this article is to highlight the importance of the etymological definition of idioms and proverbs in lexicography, especially with reference to specialized dictionaries for Sesotho sa Leboa and other African languages, as a means of preserving the African cultures embedded in these expressions. Like all other languages, Sesotho sa Leboa has idioms and proverbs embedded within the culture of the Basotho community and these expressions are used, inter alia:

- to explain a wider meaning with a very short and concise expression designed in the form of metaphor, and

- to compare the present with the past - thereby keeping alive the culture, or the potential, almost forgotten culture of the community.

\section{Definitions: Idioms and Proverbs}

The terms idiom and proverb are defined and described by various linguistic and literary scholars such as Svensén (1993) and Gouws (1999) in several different ways. These scholars include, inter alia, lexicographers and lexicologists, whose 
main perception is directed towards the possible lemmatization and the inclusion of these figures of speech in dictionary corpora and linguistic and terminographic dictionaries. Gouws (1999: 72), for instance, says the following concerning idioms:

As fully-fledged lexical items, idioms represent the lexicalization of specific semantic values. Because this lexicalization is a language specific process two languages will not necessarily have idioms to convey the same meaning.

Svensén (1993: 108) defines the term idiom as follows:

A fixed group of words with a special meaning which is different from the meanings of the individual words.

Idioms are, according to Svensén (1993: 109) "fixed combinations", not only lexically but also to some extent grammatically, and "must therefore be shown in full in the dictionary".

\section{Etymological Analysis}

The etymological definition of lexical items such as idioms and proverbs will bring a great improvement in the lexicographic development of Sesotho sa Leboa if figurative meaning is analysed more comprehensively. The available dictionaries are only concerned with the figurative meaning of idioms and proverbs without any regard for the significance of the literal meaning of these expressions. This means that dictionary users will only find the ultimate meaning of the lexical item without any knowledge of the background of the expression. In this regard Makkai (1969: 50) distinguishes between two "idiomaticity areas": "The area on the lexemic stratum will be called the first idiomaticity area, or the area of polylexonic lexemes; and that on the sememic stratum may be termed the second idiomaticity area, or the area of polysemonic sememes." This article therefore seeks to highlight the importance of taking both the literal and the figurative meanings of these expressions into consideration in order to supply the user with comprehensive definitions of these lexical items. This can be done through the compilation of a special encyclopedic dictionary which will include etymological definitions of these lexical items. This type of dictionary should have definitions concerning:

- the basic meaning of the expression,

- the relationship between the literal meaning of the expression and its real (i.e. figurative) meaning, and

- the etymological background (meaning) of the individual words in an expression.

Etymology will play a major role in the determination of the relationships 
between the literal and figurative meaning of the lexical items contained in this special type of dictionary. Etymological information will be interpreted according to the description of the term etymology as given by scholars such as Svensén (1993: 189):

Information about the etymology of words tells us their history: how they were formed and evolved and finally took the shape and meaning they have in the language of today. Etymological facts lie along the time axis, and cut straight across the other information categories, combining elements from all of them: the formal, combinational, and semantic properties of words, and the things and events in the world outside language, all make their contribution.

This means that the dictionary should answer the following questions concerning an expression such as Go ya ga maotwana hunyela 'to die':

- What is the meaning of this expression?

- What is the literal meaning of this expression?

- Why did this expression get this meaning?

- What is the meaning of the words maotwana and hunyela?

- How are these words related to 'death'?

If we were therefore to answer these questions regarding the given expression, the following would be relevant answers:

- The meaning of this idiomatic expression is 'to die', which is completely different from its literal meaning derived from the literal meaning of the individual words which constitute it.

- The literal meaning would be 'to go to the place called maotwana hunyela'.

- As far as the etymological aspect underlying the origin of this idiomatic expression is concerned, it acquired its meaning from the traditional method used by the Northern Sotho people when burying their dead. The corpse is put in an upright position in the grave with the knees up against the chest (go hunyela) facing west with the whole body covered by the skin of a beast slaughtered specifically for this purpose. The beast's meat, called mogoga, is eaten without salt immediately after the burial.

- The word hunyela means 'to shrink', or in this case, 'to bend or to squeeze the body in a sitting position in the grave with the chin leaning on the knees'. Maotwana (literally meaning 'small feet') refers to the feet of a corpse which are 'shrunken up' in the grave before being covered by soil. 


\section{Semantic (Metaphoric) Analysis}

The example discussed above confirms the fact that idioms and proverbs use known cultural words in the form of metaphor to express a secondary meaning(s). The following metaphoric comparison is usually heard when a speaker of Sesotho sa Leboa uses a proverb to confirm the truth of what he/she says. In most cases the speaker will say: Mogologolo o boletše a re: ya se rage e tla tlatša kgamelo, or Basotho ba boletše ba re: ya se rage e tla tlatša kgamelo.

This shows that these expressions did not originate in the recent but in the distant past. The semantic analysis of these figurative expressions shows that the meaning of the idioms and proverbs can be classified into three stages, i.e.:

- Stage 1: A literal meaning which makes little or no sense, as becomes clear from the above-mentioned proverb, e.g.

Ya se rage e tla tlatša kgamelo

'If it doesn't kick, it will fill the milk container.'

- Stage 2: A literal meaning which has sense even though it will not be the real meaning of the idiom or proverb, e.g.

\section{Ya se rage e tla tlatša kgamelo}

'If the cow which is being milked doesn't kick away the milk container and spill milk, the milking process will go on well and the container will ultimately be filled with milk.'

- Stage 3: Which is the real (or figurative) meaning of the idiom or proverb, which is in most cases different from the literal meaning of these expressions, e.g.

\section{Ya se rage e tla tlatša kgamelo}

'If there are no disturbances, we will have positive results.'

'If things go well, great things will happen.'

The first and second stages in the definition of these expressions will seem to be meaningless and unimportant to speakers of Sesotho sa Leboa who will always concentrate on their real or ultimate (figurative) meaning without thinking of the importance of discovering how the expressions came into existence, which is, as a matter of fact, the cultural root of the meaning of the idiom or proverb. The literal definition of the expression will help to restructure the etymology of the idiom or proverb in the sense that the user will get to know the cultural background as to how, and why, the idiom or the proverb originated.

The etymological definition of the proverb Ya se rage e tla tlatša kgamelo will show that its real meaning, explained in Stage 3 above, is metaphorically compared to the milking of a cow. This real (or figurative) sense has nothing to do with milking cows, or milk containers. In this way, familiar objects or events within the Basotho culture are used metaphorically in the form of idioms or 
proverbs which acquire figurative meaning. It is, therefore, familiar to and customary for the Basotho people to own cattle as a major livestock, and to enjoy one of the major 'fringe benefits' of owning cattle, i.e. milk.

The etymological definition of the above-mentioned proverb will help those non-mother-tongue speakers of Sesotho sa Leboa, who only know its real meaning, also to understand its real background. For instance, there are many foreign speakers of Sesotho sa Leboa who know the meaning of the proverb as it is found in dictionaries and other publications such as Rakoma's Marema-kadika, but who do not know how a cow is milked. This is true of those people who are from highly developed mostly urban areas where milking is done by machines, and who may not know the manual system which is part and parcel of the culture of rural Basotho people. To these people it will not be clear how the cow can kick the milk container. It is however, possible for these people to learn to speak Sesotho sa Leboa and to know the real meaning of this proverb without being familiar with the cultural background from which it originated.

The following analysis of the meaning of the proverb, Monna ke nku, o llela teng, and the idiom, go ba le pelo e botse, explains the importance of:

- the metaphorical comparison of the literal and the figurative meanings of the idioms and proverbs,

- the etymological (background) knowledge of the idioms and proverbs, and

- the background knowledge of the culture of the Basotho people, in order to get a full understanding of these expressions.

(a) Monna ke nku, o llela teng

Literal meaning 1: 'A man is a sheep, he cries within himself.'

Literal meaning 2: 'A man is like a sheep, he doesn't cry publicly when he is in trouble.'

Real meaning: 'A real man is strong and courageous, he doesn't expose his problems publicly.'

'A real man doesn't go around telling people his problems.' 'One cannot predict the real man's emotional status by his facial appearance.'

The etymological definition of this proverb will answer the following questions:

- Why is monna 'man' metaphorically compared to a sheep?

- What is the characteristic of a sheep as explained in this proverb, which a man possesses?

- Are all the users of this proverb aware of this characteristic?

- What is the meaning of the term monna 'man' as used in this proverb? 
The etymological explanation, or description, of this proverb will show that the word monna does not refer to an ordinary man, but to the supposed characteristic of a normal man, which is metaphorically compared to that of a sheep. There are many people who know the real or even the literal meaning of this proverb, but who cannot answer question number one. There are also many Sesotho sa Leboa language users who may not be aware of this specific characteristic of a sheep, namely that a sheep, as compared to some other animals like goats and cattle, will remain quiet even when it is being slaughtered. This silence of a sheep when it is in trouble or in difficulty is metaphorically compared to the behaviour of a real man, who will not tell anyone about his problems. The word 'real man' is used here since not all men have this characteristic. According to the Sotho custom, men who do not have this characteristic are referred to as basadi 'women'. That is why we usually hear people saying:

\section{Lebeko le se ke la mmotša, ke mosadi yola}

Literal meaning: 'Do not tell Lebeko, he is a woman.'

Real meaning: 'Do not tell Lebeko because he will go around telling other people.'

'Do not tell Lebeko because he has no courage.'

'Do not tell Lebeko the bad news because he might collapse.'

'Do not tell Lebeko because he behaves like a woman.'

\section{Or:}

\section{Makikele le ka mmotša, ke monna yola}

Literal meaning: 'Makikele, you can tell him, he is a man.'

Real meaning: 'Makikele can be told the news because he can keep the problem to himself.'

'Makikele can be given the news because he has courage.'

'Makikele can be given the news because he has the qualities of a real man.'

\section{(b) Go ba le pelo e botse}

Literal meaning: 'To have a good heart.'

Real meaning: 'Not being cruel or cunning but being kind and merciful.'

Most people know the real (figurative) meaning as well as the literal meaning of this idiom, but very few of them can trace its origin. The etymological approach to idioms like this one, especially those using organs of the body, will show the Sotho tradition assigning various functions (or responsibilities) to the various organs of the body. For instance, the heart is regarded as a controlling factor in the life of a person:

The heart helps one to make decisions. That is why one usually hears a Sotho person saying: Pelo ye nngwe e re ke mo rage, ye nngwe ya re aowa, mo tlogele, 'One heart says I should kick him, the other one says no, leave him.' 
- Doing bad things is believed to be the work of a person's heart, that is why we hear the Sotho people saying: $\mathrm{O}$ na le pelo e mpe, 'He has a bad (evil) heart (He is too bad (evil))'.

The Basotho people regard the heart as a guiding factor as far as security is concerned. This is reflected in statements such as the following:

\section{- Ke rile ge ke swanetše go sepela pelo ya ka ya gana.}

'When I was supposed to go my heart refused.'

In this way, by stopping a person from making the journey, the heart prevents him from possible danger. These are some of the traditional beliefs which are part and parcel of the Basotho culture associated with the role of the human heart.

\section{Conclusion}

This article aimed to reveal the importance of etymology in the semantic description or the definition of proverbial and idiomatic expressions in Sesotho sa Leboa. This means that the background source of the meaning of these expressions can be rediscovered if the lexicographic approach to idioms and proverbs can also consider the importance of etymological analysis of these figurative expressions. It is important to have this background knowledge underlying idioms and proverbs recorded by lexicographers in the form of specialized encyclopedic dictionaries of idioms and proverbs.

\section{References}

\section{General}

Gouws, R.H. 1999. Equivalent Relations in Translation Dictionaries. M.Phil. Study Guide. Stellenbosch: University of Stellenbosch.

Makkai, A. 1969. The Two Idiomaticity Areas in English and their Membership: A Stratificational View. Linguistics 50: 44-58.

Svensén, Bo. 1993. Practical Lexicography: Principles and Methods of Dictionary-making. Oxford: Oxford University Press.

\section{Dictionaries}

Kriel, T.J. 1988. Popular Northern Sotho Dictionary. Pretoria: J.L. van Schaik.

Kriel, T.J. and E.B. van Wyk. 1989. Pukuntšu. Pretoria: J.L. van Schaik.

Lombard, D.P. et al. 1991. Sediba. Pretoria: Via Afrika.

Louwrens, L.J. 1994. Dictionary of Northern Sotho Grammatical Terms. Pretoria: Via Afrika.

Rakoma, J.R.D. 19705. Marema-ka-dika tša Sesotho sa Lebowa. Pretoria: J.L. van Schaik.

Ziervogel, D. and P.C. Mokgokong. 1975. Comprehensive Northern Sotho Dictionary. Pretoria: Van Schaik. 